DOI: 10.1515/auseur-2017-0008

\title{
Old and New Criteria for the Governance of Political and Economic Structures on the Basis of the Bible and the Quran ${ }^{1}$
}

\author{
Norbert VARGA \\ University of West Hungary, Benedek Elek Faculty of Pedagogy \\ e-mail: vnorberrt@gmail.com \\ Andrea SZIKRA \\ University of West Hungary, Benedek Elek Faculty of Pedagogy \\ e-mail: szikra.andrea@bpk.nyme.hu
}

\begin{abstract}
This study presents a sociological analysis of the Holy Books of two world religions (the Bible and the Quran) since, according to prognoses and risk analyses, a political, economic, cultural, and religious confrontation between the world religions will be unavoidable. Special economic and political aspects also contribute to the up-to-datedness of the topic in the democratic world; in fact: the economic crisis at the beginning of the $21^{\text {st }}$ century, the difficulties of managing the crisis with traditional micro- and macroeconomic tools as well as the Europe-wide issue of migration processes. These challenges have directed our attention to alternative economic solutions and policy options, including theories on ethical basis. Modern academic discourse has recently started to direct research at leadership skills as acknowledged forms of talent. The priority of moral talent is never disputed in the Bible and the Quran, more so by certain leaders holding political or economic positions.
\end{abstract}

Keywords: Bible, Quran, leadership talent, social and economic structures, morality

\section{Introduction}

This study presents a sociological analysis of the holy books of two world religions (the Bible and the Quran) since, according to prognoses and riskanalyses, a political, economic, cultural, and religious confrontation between the world religions will be unavoidable. Special economic and political aspects

1 This study is based on the following work: Varga, N. (2013): A Biblia és a Korán politika- és gazdaságképe. 
also contribute to the up-to-datedness of the topic in the democratic world; in fact: the economic crisis at the beginning of the $21^{\text {st }}$ century, the difficulties of managing the crisis with traditional micro- and macroeconomic tools as well as the Europe-wide issue of migration processes. These challenges have directed our attention to alternative economic solutions and policy options, including theories on ethical basis. Economists and political scientists, functioning on the basis of the Christian social education, primarily analyse the works of Christian philosophers, the encyclical letters, constitutions and apostolic exhortations of popes, announcements of episcopal synods, and they go back to the original source, the Bible, only to a lesser degree. Therefore, the aim of the study has been to analyse how wealth and society appear in the primary sources.

In Judaism and Christianity, the Bible is considered to be holy and inspired by God; in Islam, the same attributes are given to the Quran. Followers of these religions believe that their respective holy books can serve as guidance in human life. Jesus and Muhammad proclaimed eschatological prophecies, which defined history as a sui generis phenomenon. Modern man is compelled to act in the same fullness of times until the end of history, when God's kingdom is finally realized on Earth. Social choices seem to have special significance during crises; however, there are clear signs of divergences between actors with powers of decision making in the European Union, considering the reasons and managing of migration as well as the responses to various problems. A specific piquancy is given to the situation as migration can also be approached as an interaction between Islamic and Christian culture.

The Biblical and Quranic images of society and economy become relevant as research tasks in contexts where questions about man and society are raised. Revealing social-economic structure is clearly not one of the primary aims of the Bible; the same cannot necessarily be claimed about the Quran. As a consequence of the above, the following methodological principles have been formulated:

1. Social and economic questions can be answered only by adopting an open attitude towards the Biblical and Quranic witness about God and not by excluding theology as an academic discipline.

2. At the same time, academic analysis makes it necessary to treat the holy books as historical documents even if such a treatment involves the risk of misinterpretation.

3. It is one of our fundamental theses that social and economic processes cannot be interpreted without the study of the cultures based on the religious cults in question.

4. Although it is not directly relevant to the topic of this article, it is important to point out that the holy books are not the only sources of either Christian or Islamic ideology, but they are the most authentic and most relevant ones; therefore, they must be given priority over other sources. 
5. The basic approach taken in this study is the acknowledgement of the influence of personal values, goals, morality, and religion on the actions and private life of the individual as well as on social and economic behaviour (Ockerfels 1992: 5).

6. The discussion of the topic requires the application of both the historicalcritical method (although many claim this framework to be outdated, it has obvious benefits pointed out by Beyme 1992) and comparative methodology suggested by Hopkin (2002) and Beyme. The two methodologies strengthen and complement each other, and together they enable the formulation of a taxonomy.

7. In the case of the holy books, disregarding the historical context, it also entails that certain passages or verses gain universal sense, thereby creating the possibility for an infinite number of interpretations.

\section{Good Practice of Power}

According to Ogilvie (973), Jackson and Butterfield (1986), the outstanding performance and leadership ability based on social skills just as social consciousness manifest themselves in the frame of talent. Csíkszentmihályi and Robinson (1986) go further, evaluating the social, economic actor with extraordinary abilities as the relation of culturally determined functional potentials and the personal skills and abilities needed for interactions in the real world. In their opinion, a time/ biological dimension should also be taken into consideration as it shows that personal skills may change with the passage of time.

Both the Old and New Testament and the Quran consider that the source of any form of power, thus state and economic power as well, is God, to whom every social actor is responsible. That can be the reason that Jesus refers to the upper world in his answer to Pilate, which is subordination for the prefect, as Gál (1987) states. Buber (1998) sees that policy is never a monologue but a dialogue between the politician and God, the 'listener'. That explains why the policy of King Ahaz is unacceptable for the Prophet Isaiah (Isa. 7.f.). Ahaz separated the sacred sphere from politics in absolute terms, which is why Isaiah declares a rival king in the form of 'Immanuel' (Isa. 7.14), who is faithful to God, therefore a theopolitician. This is the new generation of public actors who get the motivation for their political and economic activities from God. ${ }^{2}$

The political, economic leader cannot abuse his power as it leads to oppression. The phrase 'the sceptre of their oppressor' (Isa. 9.4) at the Prophet Isaiah symbolizes the cruel reign and governance. Rózsa (2001) sees the lack of freedom and independence as well as economic exploitation in this policy. A

2 According to Allport's (1980) definition, in which motivation is the stimulating power of personality. 
politician can never become a tyrant. It is well reflected in the satirical song about the Babylonian King who fell into 'Sheol', the state of complete weakness, on the judgement of Yahweh (Isa. 14.15-18). We can interpret the seriousness of the judgement properly if we keep in mind that demitization of death was considered important in Israel. Muhammad often threatens his opponents and the sinners that Hellfire will be their resting place forever (2:206). We have to mention here that theological concepts of the Pre-Islamic Arab culture did not contain the vision of 'Hell', the 'Abode of the Dead'. Belief in the underworld had no roots, so the Prophet's serious words could not particularly have a demoralizing effect on the man of the era.

Man, as the image of God, precludes the possibility that someone may tyrannize others. The poem Rom 13.3 assumes that everyone wants to live without the fear of power. The division of the Kingdom of Israel and the rebellion against Rehoboam was also caused by the fact that the king obliged the tribes to statute labour (1 Kings 12.11). The Quran suggests the legitimate nature of hierarchy among people (4:69; 6:165); however, Muhammad refused to take the prophets, including himself, as lords (3:79-80). Simon (1994) argues that the ayah 4:69 shows a particular hierarchy between the most excellent ones when it distinguishes the 'prophets', the 'steadfast affirmers of truth', the 'martyrs', and the 'righteous'. However, in earthly life, even 'wrongdoers' (6:129) might be the possessors of power. A parallel can be drawn between the concept of power in the Quran (4:58-59) and European contract theories ${ }^{3}$ because both consider the relation of the ruler and the subject as a deposit where the people is the legitimate possessor of power. Politicians should listen to their conscience to make sure to avoid dictatorial performances. Davis and Rimm (1985) find that talented people are more susceptible to moral dilemmas and are able to understand other persons' feelings and expectations. Both the two authors and Abroms (1985) warn that higher moral thinking is not always symbiotic with the concrete activity.

Members of the elite should become the servants of their people, but if rejected they can reckon that they have to share the fate of Rehoboam. According to Eliade (2006), the Ebed-Yahweh Songs (servant of Yahweh) in Deutero-Isaiah give a radically new description of the qualities of the real king and indicate the social unrest caused by the existing ruling system. This ruler turns his back to those who strike him and turns his cheeks to those who pluck them (Isa. 50.6, 53.3), carries the sorrow of others (Isa. 53.4) and changes roles with the oppressed and sets them free by carrying their iniquities. The ideal ruler reaches this by having the kings of the world be silent before him (Isa. 52.15). The text not only teaches a mere paradox but also stresses that the most humiliated is the real lord, and this way it is strongly emphasized that the real public figure regards his profession as a service. The teachings of Jesus and Muhammad point out that tribulation and

Thomas Hobbes, John Locke, Jean-Jacques Rousseau. 
persecution is not a tragedy if it is guided by a righteous purpose. They also draw our attention to the fact that their followers will have difficulties in the world (John 16.33, Q 68:4). Jesus gained his kingdom by drinking the chalice of suffering (John 19.1-11). While the Jewish interpreted his indignity as the loss of power and authority, the New Testament suggests just the opposite on the basis of Psalms 22.7. The Prophet also experienced the feeling of exclusion from the tribal society when he was deprived of the support of his clan. According to the Quran, he did not even forget that he became an orphan and lived in need (93:6-11, 94:1-4).

\section{A Political-Economic Leader as Hero in War and Peace}

The political and economic leader has to become an example (Deut. 17.19) who represents his compatriots and can be faithful to them. The way Yahweh behaved with his people in the wilderness showed the significance of the motive of faithfulness. The Old Testament judges human co-habitation in terms of faithfulness to the community when Saul argues that David is truer than him. The king referred to the fact that David had taken their community relationship more seriously and drawn more attention to it than Saul himself (1 Sam. 24.18). The social aspects of faithfulness are mentioned in the Quran as well, and it also points out that unfaithfulness costs dearly. Following the battle of the trench, the Banu Qurayza is cruelly punished, their men are executed, and their families are enslaved (33:27). ${ }^{4}$

However, the politician should keep themselves away from ultra-nationalist manifestations and ideology. In the Old Testament, ultra-nationalism is fed by the inappropriate interpretation of Yahweh's power (Isa. 1.10-20). The devastating political effect of chauvinism is presented by the reign of Zedekiah (2 Kings 25.f.). Jeremiah, on the other hand, serves as an example for the opposite as he could have been committed to the establishment because of his origin, but he refused to serve extreme national politics. This way, as Komoróczy (1992) argues, he represents the archetype of critical intellectuals who, according to Bultman's theory (1998), should not primarily lead their life on standard human judgements (1 Cor. 7.23). Muhammad is also able to keep extreme views under control; he prefers seeking compromise instead. We can think of his relationship to the Quraysh when he raises the pagan Mecca to the cultic centre of the Abrahamic religion and guarantees the central position for Mecca this way. Following this line, he plants the Mecca pilgrimage (3:97) into Islam. After occupying the town, he turns to the Quraysh leaders with the gesture of condonation and provides them high-prestige positions within the Islam community as well.

4 In his research, Bobzin (2000) exempts Muhammad from massacre and finds one of his fighters, Sad ibn Muad, responsible for it. 
In the Bible and the Quran, the fact of war is not a unique, unusual phenomenon. According to the Old Testament, the military confrontations of Israel can be interpreted as the war of God. ${ }^{5}$ From Gnilka's (2007) point of view, Joshua 3.5-11 only comes close to the concept of 'holy war', whereas the authors consider that these verses substantially include sacred war by all means. Armed wars formed an integral part of the anointed ruler's functions; therefore, he was expected to be skilled in the art of war as well. Thus, King David can chant it proudly in his song of praise: 'teaching my hands to do battle, and making my arms like a bow of brass' (2 Sam. 22.35). In Rad's (1951, 2000) opinion, the priority of the military leader's function is not conquest but liberation as well as protection of the people. ${ }^{6}$ Regarding the military strategies of the ruler, the Law of the King (Deut. 17.1420) serves as a guideline, and it also ordains that irresponsible military ambitions should be avoided. This expectation can be even stronger in case it means a politicaleconomic dependence from an empire (Isa. 30.1). King Josiah's performance in 609 $\mathrm{BC}$ was idiosyncrasy as the fate of Judah was determined by the major powers. The king was not able to comprehend or influence these power relations; thus, changes and new configurations were formed over his head. Consequently, the intervention of Judah into world politics could only happen blindly and led to failure. For the New Testament, military skills and abilities became less relevant and the apocalyptic vision of war made people horrified (Mark 13.7).

Muhammad was not brought up at a princely court, which is why he was not socialized to the art of war. In the field of warfare, the inexperienced Muslims made several false strategic decisions. In various cases, Abd Allah bin Ubayy, the leader of the Medina Hypocrites, worked out more professional military tactics than the Muslims (3:154). In spite of that, Muhammad had an excellent sense to select his military strategists as time went by. Khalid ibn alWalid, from a Meccan tribe, who defeated the Muslims in the Battle of Uhud (3:152), became a victorious military leader of the Prophet some years later. However, the Quran (3:172-174, 8:17) makes it obvious that military victory depends on Allah's decision. Muhammad always rejects military merits attributed to him and ascribes them to divine intervention. The ayah 8:17 has been interpreted in various ways. Islamic tradition views that magical power is dominant considering the military role of the Prophet (Simon 1994), while the European researcher (Watt 1956) barely finds profane combat actions. In the Quran (21:81), Solomon is invested with supernatural power, which is also sufficient to control jinns, whereas the Prophet is supported by angels in the battles. According to the Quran (4:95-96), those 'who strive and fight' in

$5 \quad$ Ex. 15.3-4, Josh. 10.14, 1 Chron. 14.14-15, 2 Chron. 14.10, Judg. 5, 23.31.

6 It is essential to look towards another aspect since Hinduism represents a similar view when discusses the duties of Kshatriyas, the second class of the four social orders according to the caste system of Hindu society, as Szenkovics (2012) claims. 
military conflicts are preferred over those ones who remain at home, which makes participation in armed conflicts even more noble. The Prophet strongly chastises (9:24) disobedient people who shirk military service. Military actions may even change the order of worship; in case of danger, a special religious service is also permitted (4:101-103).

Neither the Prophet's Arab contemporaries had professional military knowledge. At the battle of Badr (8:7, 3:13, 3:123), Muhammad, who had to face superior numbers, defeated the Meccans due to their excellent strategic location and the suitable age and ideological preparation of Muslim fighters. The Quran (8:60) draws attention to the importance of proper technical preparation as well. During the 'battle of the trench', they used a new military technology against the army that fielded ten thousand men: 'nomen est omen' the Muslims dug trenches around the undefended parts of the oasis. Prolonged siege and poor weather conditions caused the sinking of confederate morale. Importance of protecting human life also appears in warfare, and it is served by new inventions such as the coats of armour created by King David (21.80). The Quran also lays down army regulations for prisoners of war (8:67-71). Economic considerations can also be significant in this question as ransom paid for captives meant an important source of income. Asserting 'utilitarist' aspects caused a decline in military performance in many cases (8:67). Muhammad built excellent communication and information channels to their military successes (9:61). Salamon and Munif (2003) suggest that rapidity and the intensive psychic state were the keys of success against the proficient and well-equipped mercenary armies of empires.

Fitting abilities effectively to a certain social environment belongs to the intellectual dimension of talent defined by Arroyo and Sternberg (1993). This teleological conception involves the recognition of insurmountable obstacles as well as a shift towards a more optimal environment. All the reckless and premature actions seem to be suspicious (Prov. 19.2), so self-restraint becomes a significant feature (2 Tim. 1.7, Titus 1.8). The fall of Saul was also caused by his inability to make sensible, considered decisions (1 Sam. 10.9-13). Patience ('sabr') is a key concept in the Quran (it occurs 103 times), which is rooted in the concept of virtue ('muruwwa') ${ }^{7}$ from pre-Islamic times and an important feature of the warrior (2:250). However, Gedaliah's fate warns us that blind nationalism will always take actions against peace policy.

The king brings peace (Psalms 72, 3.7), which is a beneficial condition and the most optimal one. Peace is more than merely the antithesis of war; nevertheless,

$7 \quad$ Gecse (1980) attributes the following meanings to this term (which is considered a fundamental ethical concept for Bedouin tribes): masculinity, courage, blood feud, and hospitality. Goldziher (1980) reflects the meaning by the word 'virtue' and defines it as a religion without a specific moral philosophical content (however, he erred in combining the concepts of religion and morality). Armstrong (1998) and Watt (2000) recommend 'tribal humanism' as a terminus technicus. 
it is not Paradise on earth but the state in which things and the human world are intact and fulfil their intended purpose. Peace turns into the opposite of war and takes on a political meaning as soon as the established beneficial state of affairs is threatened by external enemies. Buber (1998) states that the essence of Isaiah's theopolitical teaching is the call for serenity and peace (Isa. 18.4, 32.15), which reflects his ideas about the proper political attitude. Jeremiah points out that in times of political struggle and war the alternatives of submission or resistance are guided by practical considerations and not by principles; it is impossible to outline general norms based on historical incidents because in some cases one is needed, in other cases the other. The work of Jesus on earth was characterized by the advocacy of peace. It is a greeting of peace that he sends out his 72 disciples with (Luke 10.5-6), and upon weeping over Jerusalem he explicitly claims that the society cannot perceive the practicalities that would serve its peace (Luke 19.42). The Messiah draws a sharp line between the profane and the transcendent interpretation of peace by saying: 'Peace I leave for you; my Peace I give to you. Not in the way that the world gives, do I give to you.' (John 14.27).

\section{Some Elements of the Optimal Economic System}

Politicians and economic leaders need to fight against harsh economic systems that undermine social equality and consign the poor to slavery (2 Kings 4.1). Rulers should not acquire wealth with the sole purpose of ensuring better livelihood for themselves or in a way that would increase social burden on others. Instead, they should help the oppressed and the pauper in regaining their freedom and use positive discrimination in this area of life as well. Several books in the Old Testament (Ex. 22.24, Lev. 25.36) highlight the importance of lending money, at the same time stating that creditors are not allowed to charge interest on loans given to members of their own faith community. The Book of Deuteronomy (15.7-10) goes even further in pointing out that the duty of granting loans to those in need applies even in the seventh year, 'the year of release'. Wages must not be kept low by the elite driven by self-serving greed or egoistic indulgence. This commandment was brought into King Jehoiakim's attention by the Prophet Jeremiah, who also warned the sovereign that acting against it would prove ignorance of what it takes to be a legitimate monarch in JHWH's eyes (Jer. 22.13-19). It is on the same basis that Allah condemns the elite for trying to exclude social groups other than their own from the economic competition. They want to make trade optimal for themselves by changing the condition 'Lengthen the distance between our journeys' (34:19). The Quran clarifies its teaching in economic terms and uses the logic of merchants to claim that fair and honest investments on earth yield profit in the afterlife $(2: 261)$. 
Surah 64 is titled 'The Mutual Disillusion', an expression taken from trade and applied to those who leave the true way. In verse 6:31, the words 'those will have lost' - another term from the world of business - are used to describe those who 'deny' the benefits of meeting Allah. Indulgers of worldly desires will be 'fully repaid for their deeds' (11:15), but they will not escape punishment in the afterlife, either. According to an interpretation of verse 70:18 by Salamon and Munich (2003), the collection of private wealth can be considered legitimate only if there is a hint for social motivation. An important segment of social redistribution is revealed in verse 9:60, which codifies the group of those eligible for sadaqa.

The Prophet makes a lot of effort to regulate the rules of inheritance (2:180-182, 5:106-108). Social anomy is a result of a shift from a matriarchal establishment to a patriarchal one. In the matrilineal structure, guardians were appointed on the female line and managed the assets with communal interests in mind. Watt's analysis (1956) claims that the emergence of patrilineality entailed a new phenomenon: the guardian stepped forth as an individual and passed property down on the male line. In this new structure, guardians often abused their rights and treated the assets trusted to them as their own. Frequent cases of abuse are assumed to have been postponing the marriage of female orphans or, upon marriage, withholding their dowry (4:4). Quranic instructions (4:7) put an end to the legal practice of depriving widowed wives or daughters of the deceased father of their share of inheritance. Levirate marriage (Deut. 25.5-10) was a widespread institution in the Middle East in ancient times. The Quran (4:19) prohibits abuse within this type of marriage, makes it unlawful to deny bridal money, and forbids women to bail themselves out.

Some researchers ${ }^{8}$ argue that by questioning the established practice of usury and charging interest, Muhammad created a unique economic philosophy influential to the present day in the Islamic world. The Prophet arrived at his ideas about gradually abolishing usury and interest. The verses originating from the Mecca period (3:130, 30:39) already speak disapprovingly of such ways of acquiring wealth, but this disapproval is crystallized into explicit prohibition from ayah 4:164 onwards. In the Arabic system, if a debtor could not repay the debt and the interest, new interest was levied on top of the previous one. The Prophet's aim was to have debtors' earlier usuries cancelled after their conversion to Islam $(2: 278-281) .^{9}$

8 Watt (1956), Firth (1963), Rodinson (1978), Rostoványi (2004), Kaleem and Ahmed (2010) these sources also indicate the differences in the interpretation of usury and interest. In Balala's reading (2011: 47-54), the prohibition of 'riba' refers to trading with credit, whereas the prohibition of 'gharar' is meant to apply to trade with unnecessary risks and uncertainty. He also claims that the undifferentiated identification of 'riba' with interest by most contemporary researchers of law and Islamic finance is a mistaken interpretation.

$9 \quad$ Islamic types of banks, which are becoming increasingly widespread in Europe as well, do not recognize the option of granting loans on interests but allow for a 'system of dividends'. To avoid interest, they use the system of Profit and Loss Sharing. Mainstream Islam only accepts one sort of loan, that of a charitable loan (qard hasan), which is a loan free of interest, and 
Madigan (2008: 109) carries out an interesting comparative analysis between the semantics of the Arabic word 'rabb' and the English 'lord'. The English expression is a blend from the words 'loaf' and 'ward', which clearly shows that a lord used to be a bread-keeper responsible for providing his folk with food. In Arabic language, 'rabb' is a synonym for sovereignty (including God), and this meaning, similarly to that of the English 'lord', involves the idea of fulfilling fundamental human needs. This suggests, in a theodicean reading of the holy books, that we owe each segment and moment of our existence to God honoured as Lord. In the New Testament, the story of poor Lazarus (Luke 16.1931) can be mentioned as a parable with a socializational intention and one that attacks self-serving affluence. This does not mean that the Gospel according to Luke would deny or belittle the economic system. Money is referred to in derogative terms as the 'iniquitous mammon' (Luke 16.11); even so, it has to be handled faithfully, and that entails refusing interest and usury (Luke 6.35). The Quran uses phrases with negative moral overtones to talk about worldly finery and vanities because these distract us from transcendental qualities. In Kaleem and Ahmed's (2010) interpretation, verses 17:26-29 are directed against wastefulness, extravagance, and hoarding wealth in precious metals; at the same time, the text encourages meaningful spending especially for the sake of the common good. The importance of protecting communal and private property is shown by the fact that stealing a quarter of a dinar or more was punished, in a uniquely Arabic way, by cutting off the thief's hand (5:38). Besides the geopolitical features, it is the strong social sensitivity of Islam that is revealed by a practice linked to sacrifice as well: the flesh of the sacrificial animal offered to God does not feed gods but is supposed to be given to the poor.

Politicians and economic leaders have to carry out planning even if they have limited command over the future (Prov. 21.31, 16.9). In order to become a competent leader, an individual has to master six areas (Sisk 1993), and one of these is orientation towards the future. Sensible men reckon with the unpredictable discrepancy between their plans for the future and the actual realization of these plans. Disregarding this deficit threatens with misunderstanding the role of a political or economic leader and mistaking human beings for God. Both the Book of Proverbs and the Quran (18:32-44) warn their readers against false certainty in believing that man can control the future. Both texts point out that although unpredictability cannot be totally eliminated, its level can be decreased. That is the reason why in verse 1:6 of the Quran and verse 27.11 in the Book of Psalms God the Creator is asked to lead believers on a straight path. This request is even more emphatic in the Quranic approach (3:8) due to the lack of a clear-cut decision between free will and predestination. Murjites,

payback time is not set in advance. The Quran (2:245, 64:17) interprets it as a loan given to God, and it serves as the basis of microfinancing institutions (MFIs) in the $21^{\text {st }}$ century. 
Mutazilites, and Kharijites professed their belief in free will and excluded the possibility of Allah setting human heart to do wrong. They described the ability to choose as the most significant attribute of human beings because this is what others base their judgements about an individual on. In ayah 17:16, another Quranic tendency is manifested: it implies that the omnipotence of God predetermines everything. Fatalistic interpretations were encouraged by the fact that Muhammad experienced failure after failure at the beginning of his career. Occasionalism was established by Asari (873-935) as a theory that could mediate between the two schools. According to him, the omnipotence of the deity leaves space for individuals to 'receive' or internalize God's decision. According to Galwash (1968), mainstream Sunnism denied free will and defined human life as fate, that is existence independent of the individual. This approach changed in the $20^{\text {th }}$ century due to what Gnilka (2007) identifies as the decolonizational struggle, since the dogma of predestination legitimizes existing social and economic structures. Shia sociologist Shariati (1979) finds no antinomy between determinism and human freedom.

Politicians and economic actors need to take it into account that future circumstances are uncertain (Eccles. 8.7); even their own future condition is beyond their control (Eccles. 9.1b). When analysing the Quranic verse 19:21, Asad (1980) suggests that God sometimes induces events that seem unpredictable and incomprehensible to human beings. This leads Al-Ghazali (2000) to wonder why Jews do not acknowledge the all-surpassing power of God. ${ }^{10} \mathrm{He}$ also reminds public actors that large-scale reforms fulfilling all needs, dissolving all violent divisions, and eliminating all oppressive abuse cannot be carried out without JHWH's or Allah's contribution. This reflects the way such reforms are inseparably linked to Jesus and his mission in the New Testament (Rev. 21).

\section{Epilogue: Is There Any Hope?}

As we have seen, modern academic discourse has recently started to direct research at leadership skills as acknowledged forms of talent. Holy books clearly describe the aspects of managing social-economic structures; moreover, the religious texts encourage public actors to follow these models. The priority of moral talent is never disputed in the Bible and the Quran, more so by certain leaders holding political or economic positions.

In the ummah, the optimal Islamic community, each person is an individual in a spiritual and legal sense but is realized as a member of the community from political and economic aspects. The Quran did not abolish stratification based on tribal affinity and kinship, it only complemented it with the principle of

10 The Quran accepts the teaching of Mary's virgin birth. 
redistribution on religious grounds. This created a very strong sense of social sensitivity within the Islamic economy at all times since in the Quran (2:275) trade and charity are closely linked. The guiding principle is that positive economic activity is encouraged, whereas the possibility of making profit by charging usury or without taking a risk is rejected. Charity reduces the level of inequality in the society, and helping the poor is blessed by God. The concept of charity is not limited to money and benefits in kind: those in need should also be provided with knowledge and experience. Nevertheless, the Quran does not wish to abolish the unequal distribution of wealth in society.

The methodology of Muhammad's understanding of society and economy is close to that of the Old Testament inasmuch as it is motivated by divine inspiration. The presumption that political and economic status originates from God leaves no place for compromise, and the human component seems impotent. The current restoration of the right cult also entails a change in social-economic relations. Relationship to God determines the way the individual relates to other human beings and to the social-economic environment. Based on the model of the Quran and the Old Testament religion, economy and political aspects cannot be separated from each other. By contrast, such a separation is possible in the New Testament because of its claim that the whole message of the Bible refers to Christ.

It follows from all this that there is a marked difference between Jesus' and Muhammad's attitude to social-economic structures: the teachings of Jesus remained radically eschatological in nature, whereas Muhammad's revelations took on worldly features. The community of the Old Testament generally accepted and accepts the theory of "dina demalchuta dina - the law of the land is the law" (Ben-Dor-Pedahzur 2008: 228.), which ensured their survival under the reign of a foreign power for thousands of years. Obviously, it did not exclude the possibility of creating a body politic, but it is an eternal question who is entitled to do that. In history, it was attempted several times to construct a political formation referring to the Messiah. The community of the New Testament continued to be described in religious terms that influences social-economic structure this way; however, following the example of Jesus, it does not appear as an independent political entity. By derogation, the community of the Quran has political and economic attributes. Muhammad did not define in the Quran what political or economic system should serve as a framework for the Islamic society, but the main organizing principle is doubtlessly 'al-islam din vad aula', that is Islam is the symbiosis of religion and state. For Muslims, any political or economic system can be legitimate only if it guarantees the attainment of Islamic goals.

Based on the teachings of the Bible, Wolf (2001) draws the conclusion that whoever abandons the God of Hope (Deus spei), that is the deity in whom the faith of Israel's patriarchs, prophets, great kings, and the Jesus of Nazareth is grounded, and uses the virtue of humanity as an independent capacity to worship the Idol of 
Hope (Deus spes) instead, either imposes inhumanely impossible requirements on human beings or relativizes the expectance of the new world in a miserable way. Hope as expressed in the Bible promises new creation, which surpasses the potentials of politicians and economic leaders. At the same time, this promise encourages them to take the steps that lie within their scope of competence in order to achieve the intended goal. Followers of the Old Testament experience the hope in Earth at every Sabbath. The Quran (16:8) extends hope by calling attention to Allah's ability to create several things that no one knows about but which are helpful for mankind. As Hentschel (2008) maintains, the Epistle of Paul to the Colossians (3.10) expresses the hope that guarantees constant innovation for humans as creation is permanently renewed in the image of its maker.

Such a promise about the God of Hope provides public actors and economic leaders with a weapon against two kinds of disappointment. Some find consolation in life after death and cause disappointment by keeping hope in the black box of the immutable history. Others claim that they have the power to create the heaven of salvation even on Earth and cause disappointment by hopelessly ruining the present. As a contrast, public actors and economic leaders oriented towards the future can trust the word of promise and, as such, are able to remain radically hopeful despite the relativity of small steps and the irreversibility of future.

The unceasing contraction of the world cannot promote to interpret the above discussed questions; however, the continuous pulsation of the world makes it possible to extend the 'hermeneutic circle', i.e. the circle of common, thinking people since both holy books address all creatures of God. Therefore, the authors highlight the necessity of academic and interdisciplinary dialogue between cultures and cults, and they hope that as a 'spill-over' effect it can gradually extend to social and economic leaders as well.

The question needs to be asked whether there is any hope to manage on the basis of holy books, the cataclysms leading to the economic crisis in 2008, and the migration flows. Our answer is clear: yes, there is; however, it is necessary to lay down that it demands a Copernican revolution, which also means a paradigm shift for economic and political decision makers. It seems that instead of economic and political decisions claimed to be rational, we receive eternal economic and political principles from the transcendent era that was almost never taken seriously and was exiled in the world of irrationality by leaders of modern-day Europe. However, the implementation of these principles is always an individual decision, the honesty of which can become transparent in the decision-making process. 


\section{References}

ABROMS, K. I. 1985. Social Giftedness and Its Relationship with Intellectual Giftedness. In: Freeman, J. (ed.), The Psychology of Gifted Children. New York: John Wiley and Sons Ltd. 201-218.

Al-GHAZALI, S. M. 2000. A Thematic Commentary on the Qur'an. Transl. from the Arabic by Ashur A. Shamis. Herndon: The International Institute of Islamic Thought.

ALLPORT, G. W. 1980. A személyiség alakulása. Budapest: Gondolat Könyvkiadó. ARMSTRONG, K. 1998. Mohamed: az iszlám nyugati szemmel. Budapest: Európa Könyvkiadó.

ARROYO, C. G.-STERNBERG, R. J. 1993. Against All Odds: a View of the Gifted Disadvantaged. In: Wallace, B.-Adams, H. B. (eds), Worldwide Perspectives on the Gifted Disadvantaged. Bicester, UK: AB Academic Publishers. 29-43.

ASAD, M. 1980. The Message of the Qur'an. Gibraltar: Dar al-Andalus.

BALALA, M.-H. 2011. Islamic Finance and Law. Theory and Practice in a Globalized World. New York: Palgrave Macmillan.

BEN-DOR, G.-PEDAHZUR, A. 2008. Az iszlám fundamentalizmus egyedisége és a nemzetközi terrorizmus negyedik hulláma. In: Krizmanits J. (ed.), Vallási fundamentalizmus. Tradíció, politika és radikalizmus az iszlám világban. Budapest: Politológiai Párbeszéd Társaság-L’Harmattan Kiadó. 223-241.

BEYME, von K. 1992. Die politischen Theorien der Gegenwart. Opladen: Westdautscher Verlag.

BOBZIN, H. 2000. Mohammed. Munich: C.H. Beck.

BUBER, M. 1998. A próféták hite. Budapest: Atlantisz Könyvkiadó.

BULTMANN, R. 1998. Az Újszövetség teológiája. Budapest: Osiris Kiadó.

CSÍKSZENTMIHÁLYI, M.-ROBINSON, R. E. 1986. Culture, Time and the Development of Talent. In: Sternberg, R. J.-Davidson, J. E. (eds), Conceptions of Giftedness. Cambridge: Cambridge University Press. 264-284.

DAVIS, G. A.-Rimm, S. B. 1985. Education of the Gifted and Talented. Englewood Cliffs, New Jersey: Prentice Hall Inc.

ELIADE, M. 2006. Vallási hiedelmek és eszmék története. Budapest: Osiris Kiadó. ENDREFFY, Z. (transl.). 1986. John Locke: Értekezés a polgári kormányzat igazi eredetéról, hatásköréról és céljáról. Budapest: Gondolat Kiadó.

FIRTH, W. R. 1963. Elements of Social Organization. Boston: Beacon Press.

GALWASH, A. A. 1968. The Religion of Islam. Cairo: Al-Shaab Printing House.

GÁL, F 1987. János evangéliuma. Budapest: Szent István Társulat.

GECSE, G. 1980. Vallástörténet. Budapest: Kossuth Könyvkiadó.

GNILKA, J. 2007. Biblia és Korán. Budapest: Szent István Társulat.

GOLDZIHER, I. 1980. Az iszlám. Budapest: Magvető Könyvkiadó. 
HENTSCHEL, G. 2008. „Miért kérdezed a nevemet?” A közeli és a távoli Isten. In: Benyik, György (ed.), Szegedi Nemzetközi Biblikus Konferencia. Szeged: JATE Press. 113-119.

HOPKIN, J. 2002. Comparative Methods. In: Marsh, D., Stoker, G. (eds), Theory and Methods in Political Science. London: Palgrave-MacMillan. 249-267.

JACKSON, N. E.-Butterfield, E. C. 1986. A Conception of Giftedness Designed to Promote Research. In: Sternberg, R. J.-Davidson, J. E. (eds), Conceptions of Giftedness. Cambridge: Cambridge University Press. 151-181.

KALEEM, A.-Ahmed, S. 2010. The Quran and Poverty Alleviation. A Theoretical Model for Charity-Based Islamic Microfinance Institutions (MFIs). Nonprofit and Voluntary Sector Quarterly 39(3): 409-428. (http://nvs.sagepub.com/ content/39/3/409.refs.html).

KOMORÓCZY, G. 1992. Jeremiás, Jeruzsálem, Nebúkadreccar. In: Komoróczy, G. Bezárkózás a nemzeti hagyományba. Budpest: Századvég Kiadó. 199-230.

MADIGAN, D. S. J. 2008. Az ige népe: János olvasása muzulmánokkal. In: Benyik, György (ed.), Szegedi Nemzetközi Biblikus Konferencia. Szeged: JATE Press. 103-112.

OCKERFELS, W. 1992. Kis katolikus társadalomtan. Katolikus Társadalmi Akadémia.

OGILVIE, E. 1973. Gifted Children in Primary Schools. Macmillan Educ. Ltd. RAD, von G. 1951. Der Heilige Krieg im alten Israel. Zürich: Zwingli-Verlag. 2000/2001. Az Ószövetség teológiája I-II. Budapest: Osiris Kiadó.

RODINSON, M. 1978. Islam and Capitalism. Austin: University of Texas Press.

ROSTOVÁNYI, Zs. 2004. Az iszlám világ és a Nyugat. Budapest: Corvina.

RÓZSA, H. 2001. Üdvösségközvetítök az Ószövetségben. Budapest: Szent István Társulat.

SALAMON, A.-MUNIF, A. F. 2003. Saría. Allah törvénye. Az iszlám jog különös világa. Budapest: Press Con Kiadó.

SHARIATI, A. 1979. On the Sociology of Islam. Berkeley: Mizan Press.

SIMON, R. (ed.). 1994. Korán. A Korán világa. Budapest: Helikon Kiadó.

SISK, D. A. 1993. Leadership Education for the Gifted. In: Heller, K. A.-Mönks, F.

J.-Passow, A. H. (eds), International Handbook of Research and Development of Giftedness and Talent. Oxford: Pergamon. 491-505.

SZABÓ, M. (transl.). 1984. Platon: Állam. In: Platon összes múve I-III. Budapest: Európa Könyvkiadó.

SZENKOVICS, D. 2012. Ahimszá, egy központi gondolat Móhandász Karamcsand Gándhí filozófiai gondolkodásában. Erdélyi Múzeum 74(1): 48-61. (http://eda. eme.ro/handle/10598/26154). Downloaded on: 1 July 2015.

The Noble Qur'an. http://quran.com. Downloaded on: 25 September 2014. 
The Sacred Bible. 2009. Catholic Public Domain Version, Original Edition. Ronald L. Conte Jr., transl. and ed. http://www.sacredbible.org/catholic/index. htm. Downloaded on: 25 September 2014.

VÁMOSI, P. (transl.). 1999. Thomas Hobbes: Leviatán. I. Budapest: Kossuth Könyvkiadó.

VARGA, N. 2013. A Biblia és a Korán politika- és gazdaságképe. KolozsvárBudapest: Exit Kiadó-Marczibányi Téri Múvelődési Központ.

WATT, W. M. 1956. Muhammad at Medina. Oxford, UK: Clarendon Press.

WOLFF, H. W. 2001. Az Ószövetség antropológiája. Budapest: Harmat-PRTA. 